\title{
ॠUSGS
}

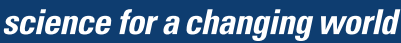

Prepared in cooperation with the Bureau of Ocean Energy Management, Regulation and Enforcement

\section{Proceedings of a Coastal and Marine Spatial Planning Workshop for the Western United States}

Open-File Report 2011-1152

U.S. Department of the Interior U.S. Geological Survey 
Front cover: Photograph by Jim Jacobi, U.S. Geological Survey Ridge to Reef Project, Pacific Island Ecosystems Research Center Back cover: Photograph by David Woodson, U.S. Geological Survey, Western Fisheries Research Center 


\section{Proceedings of a Coastal and Marine Spatial Planning Workshop for the Western United States}

By Lyman Thorsteinson, Derrick Hirsch, David Helweg, Amardeep Dhanju, Joan Barminski, and Richard Ferrero

Cavallo Point Lodge, Fort Baker, Sausalito, CA

December 1-2, 2010

Prepared in cooperation with the Bureau of Ocean Energy Management, Regulation and Enforcement

Open-File Report 2011-1152

U.S. Department of the Interior

U.S. Geological Survey 


\section{U.S. Department of the Interior \\ KEN SALAZAR, Secretary}

\section{U.S. Geological Survey \\ Marcia K. McNutt, Director}

U.S. Geological Survey, Reston, Virginia: 2011

For more information on the USGS-the Federal source for science about the Earth, its natural and living resources, natural hazards, and the environment, visit http://www.usgs.gov or call 1-888-ASK-USGS.

For an overview of USGS information products, including maps, imagery, and publications, visit http://www.usgs.gov/pubprod

To order this and other USGS information products, visit http://store.usgs.gov

Suggested citation:

Thorsteinson, L., Hirsch, D., Helweg, D., Dhanju, A., Barminski, J., and Ferrero, R., 2011,Proceedings of a Coastal and Marine Spatial Planning Workshop for the Western United States: Cavallo Point Lodge, Fort Baker, Sausalito, CA, December 1-2, 2010, U.S. Geological Survey Open-File Report 2011-1152, 24 p.

Any use of trade, product, or firm names is for descriptive purposes only and does not imply endorsement by the U.S. Government.

Although this report is in the public domain, permission must be secured from the individual copyright owners to reproduce any copyrighted material contained within this report. 


\section{Contents}

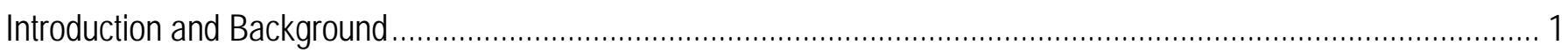

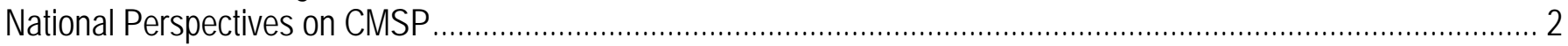

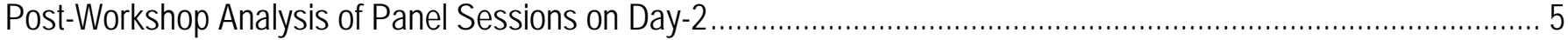

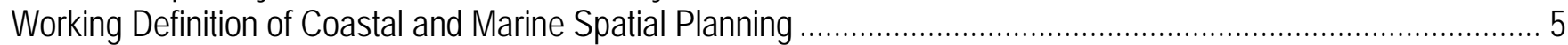

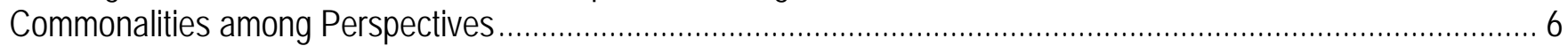

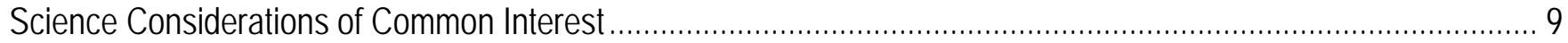

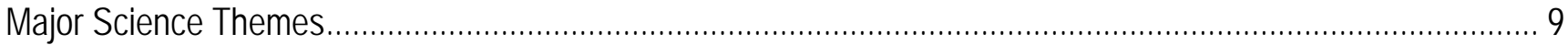

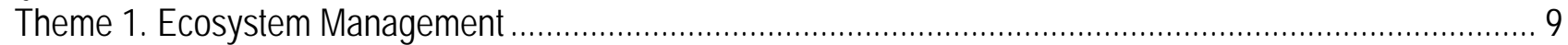

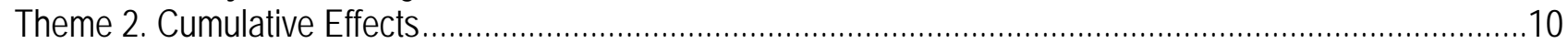

Theme 3. Social Sciences / Traditional Ecological Knowledge...............................................................10

Theme 4. Achieving Scientific Efficiencies Through Improved Coordination and Cooperation .........................10

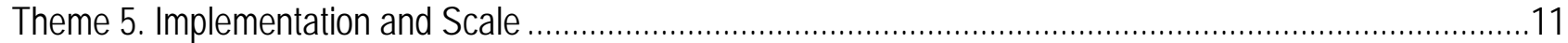

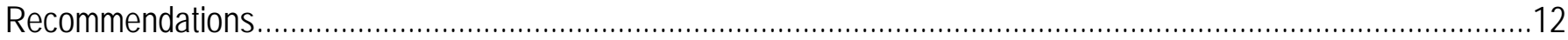

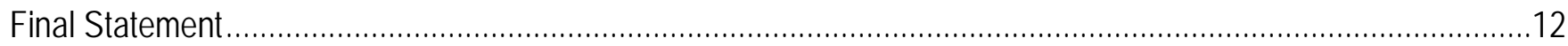

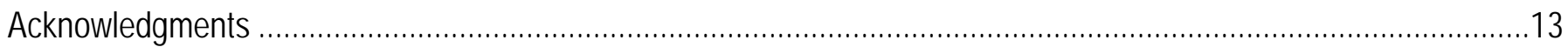

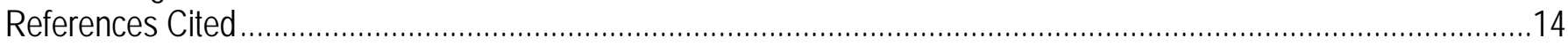

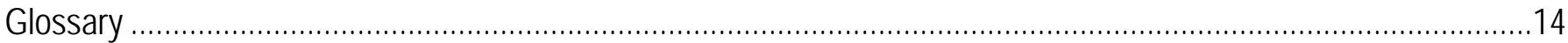

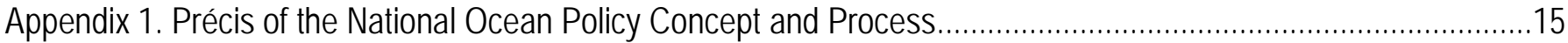

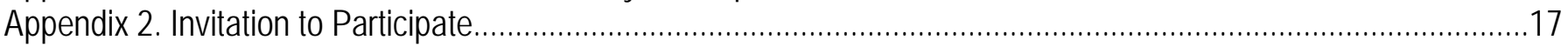

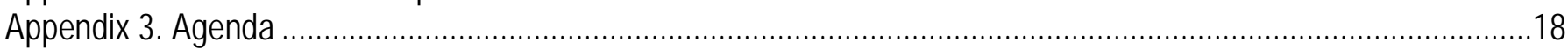

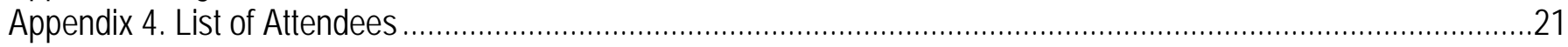

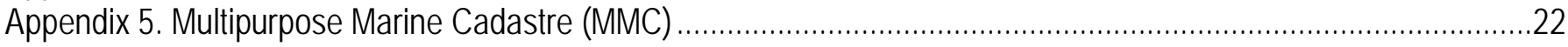

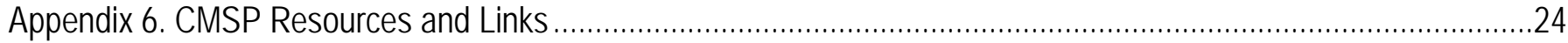

\section{Figure}

Figure 1. Guiding ecological principles for marine spatial planning (from Foley and others, 2010)........................ 7 
This page left intentionally blank 


\title{
Coastal and Marine Spatial Planning Workshop for the Western United States
}

\author{
By Lyman Thorsteinson, Derrick Hirsch, David Helweg, Amardeep Dhanju, Joan Barminski, and Richard Ferrero
}

\section{Introduction and Background}

Recent scientific and ocean policy assessments demonstrate that a fundamental change in our current management system is required to achieve the long-term health of our ocean, coasts, and Great Lakes in order to sustain the services and benefits they provide to society. The present (2011) speciesand sector-centric way we manage these ecosystems cannot account properly for cumulative effects, sustaining multiple ecosystem services, and holistically and explicitly evaluating the tradeoffs associated with proposed alternative and multiple human uses. A transition to an ecosystem-based approach to management and conservation of coastal and marine resources is needed.

Competing uses and activities such as commerce, recreation, cultural practices, energy development, conservation, and national security are increasing pressure for new and expanded resource usage in coastal marine ecosystems. Current management efforts use a sector-by-sector approach that mostly focuses on a limited range of tools and outcomes [for example, oil and gas leases, fishery management plans, and Marine Protected Areas (MPAs)]. A comprehensive, ecosystem-based, and proactive approach to planning and managing these uses and activities is needed. Further, scientific understanding and information are essential to achieve an integrated decision-making process that includes knowledge of ecosystem services, existing and possible future conditions, and potential consequences of natural and anthropogenic events. Because no single government agency has executive authority for coastal or ocean resources, conflicting objectives around competing uses abound.

In recent years, regional- and state-level initiatives in Coastal and Marine Spatial Planning (CMSP) have emerged to coordinate management activities. In some respects, the components and steps of the overall CMSP process are similar to how existing ocean resources are regulated and managed. For example, the Bureau of Ocean Energy Management Regulation and Enforcement (BOEMRE) uses spatial planning exercises in State Renewable Energy Task Force meetings to identify competing and conflicting ocean uses, and to delineate areas suitable for renewable energy development. Similarly terrestrial areas such as in national parks and national wildlife refuges managed by the Department of the Interior (DOI) prepare management plans for preservation and restoration of species and habitats of concern, some of which are protected by law. The analogy to CMSP is clear - multiple users and multiple expectations, resulting in the requirement to establish spatial plans for management of different resources and different ecosystem services.

A two-day workshop on December 1-2, 2010, was convened for DOI representatives and several key non-DOI participants with roles in CMSP as a step toward clarifying national perspectives and consequences of the National Ocean Policy for the West (appendix 1). Discussions helped to develop an understanding of CMSP from the federal perspective and to identify regional priorities. An overarching theme was to promote a better understanding of current and future science needs. The workshop format included briefings by key Federal agencies on their understanding of the national 
focus followed by discussion of regional issues, including the needs for scientific information and coordination. The workshop also explored potential science contributions by Federal agencies and others; utilizing current capabilities, data, and information systems; and provided a foundation for possible future regional workshops focusing in turn on the West Coast Region (California, Oregon, and Washington), Pacific Islands (sometimes referred to as Oceania) and Alaska.

Participants were asked to share information in the following areas, recognizing that the purpose would be to learn more about the national perspective (see appendixes 2-4):

- Explore how the Western U.S. (Alaska, Pacific Islands, and West Coast Region) might implement the vision for CMSP put forth by the Interagency Ocean Policy Task Force in the National Ocean Policy and Executive Order [with input from BOEMRE, U.S. Geological Survey (USGS), National Oceanic and Atmospheric Administration (NOAA), and others].

- Clarify the range of strategic science priorities that CMSP generates within and across DOI, Department of Commerce (DOC), and other Federal entities.

- Communicate DOI partner information needs and priorities to appropriate levels of bureau management within the DOI and with other agencies.

The goals of the workshop were to lay the foundation for improved communication among DOI bureaus and partners and to expand our ability to provide appropriate and timely science that is responsive to regional needs put forth in the July 19, 2010, Executive Order (E.O. 13547) by the President. The Executive Order adopts the final recommendations of the Interagency Ocean Policy Task Force, including the "Framework for Effective Coastal and Marine Spatial Planning", hereinafter known as "Framework". This report is an effort to capture and synthesize initial regional perspectives of CMSP and its implementation presented at the workshop.

\section{National Perspectives on CMSP1}

On July 19, 2010, President Obama signed Executive Order 13547, which established the Nation's first comprehensive national policy for the stewardship of the ocean, our coasts, and the Great Lakes. The establishment of a policy was recommended by the U.S. Commission on Ocean Policy in 2004. The National Policy adopts the Final Recommendations of the Interagency Ocean Policy Task Force and directs Federal agencies to take steps to implement the recommendations. Additionally, it creates an interagency National Ocean Council comprising 27 agencies, offices, and departments to strengthen ocean governance and provides sustained, high-level focus on the national priority objectives identified in the Final Recommendations for action to advance the National Policy.

One of the priority objectives of the National Policy is a flexible framework for effective coastal and marine spatial planning to address conservation, economic activity, user conflict, and sustainable use of the ocean, coasts, and the Great Lakes. As stated in the Final Recommendations, "Coastal and marine spatial planning is a comprehensive, adaptive, integrated, ecosystem-based, and transparent spatial planning process, based on sound science, for analyzing current and anticipated uses of ocean, coastal, and Great Lakes areas.” CMSP identifies areas most suitable for various types or classes of activities in order to reduce conflicts among uses, reduce environmental impacts, facilitate compatible uses, and preserve critical ecosystem services to meet economic, environmental, security, and social objectives. In practical terms, CMSP provides a public policy process for society to better determine

\footnotetext{
${ }^{1}$ Video of presentations at: $h$ ttp://media.wr.usgs.gov/cmg/cmsp/.
} 
how the ocean, coasts, and Great Lakes are sustainably used and protected—now (2011) and for future generations.

Scientific understanding and information are central to achieving an integrated and transparent planning process. Natural, social, and cultural sciences can inform decisions about how to achieve societal objectives from the Nation's ocean, coastal, and Great Lakes waters, now and into the future, while maintaining ecosystem integrity. Built on this foundation of sound science, this new system for planning should facilitate maintenance of essential ecosystem services, encourage compatible uses, minimize conflicts, evaluate tradeoffs in an open and transparent manner, and include substantial and meaningful stakeholder involvement.

Coastal and Marine Spatial Planning is different from other sector specific spatial planning initiatives in several ways:

- It is comprehensive:

- Strives to include all interested parties at the table from the beginning,

- long-range planning is independent of specific activity, and

- $\quad$ specific locations are managed within regional context.

- It is integrated:

- CMSP is not focused on specific activities or sectors, and

- it includes human uses and ecosystem health.

- It does not prescribe, a priori, a specific management outcome:

- Instead, it allows regional planners to create a suite of objectives for how they wish to use and conserve their ocean waters and resources.

- It provides a means to balance multiple and competing interests in a neutral way, not constrained by single, limited statutory mandates.

The planning process includes two distinct pieces: (1) determining what today looks like (that is, present state), and (2) predicting what tomorrow might look like. In order to develop a common knowledge base, certain questions need to be asked:

- What are the current uses of the ocean, coastal, and Great Lakes areas?

- What is the physical structure of a region, and what are its primary flow components?

- What are the species and habitats within a region?

- Where are the important and vulnerable areas and services?

- What ecosystem goods and services derive from a region?

- What are the life histories of species of concern within the region?

- What are the interests of indigenous people?

- What are the cultural (maritime heritage) interests? What are the cultural resources (archeological and maritime) within a region - these are separate from special interests and represent resources that National Park Service (NPS) units are responsible for protecting (for example, historic structures and sunken vessels).

- What are the patterns of current and emerging ocean uses?

- Where are the areas of current or project conflict and compatibilities among those uses?

- What are the existing laws and regulations?

The second part of planning examines where we want to be in the future.

- Use principles of ecosystem-based management to develop understanding of the complexities of the environment and the cumulative effects of humans interactions. CMSP recognizes that humans are part of the ecosystem. 
- Recognize regional goals and objectives, including the importance of the economic benefits from our oceans and coasts, as well as recognizing various non-use values such as sitting on the beach and watching the sun set. Regional goals will include restoration of ecosystems for nonhuman uses such as the salt ponds to wetlands in San Francisco Bay, or new MPAs along the California coast.

- Regional planning should consider long-term outcomes, years and decades beyond the initial planning phase. The regional plan will need to allocate ocean uses in ways that maximize their benefits, minimize their effects, and sustain the area's ecosystem services for this and future generations.

- Develop scenarios of potential future uses and evaluate potential cumulative effects. For example, with respect to potential offshore wave facilities, would we want to have 100 or 1,000 or 10,000 facilities in the future and what would be their intended and unintended effects? Another example might include additional national wildlife refuges, marine sanctuaries, or national seashores, and evaluating the effects of these.

Coastal Marine Spatial plans should provide a framework for improved coordination and cooperation among Federal, State, tribal, and local enforcement agencies. To the extent permitted by existing laws and regulations, this cooperative regional approach should build productive partnerships that would encourage sharing of information and best practices, help foster mutually agreed upon enforcement priorities and strategies, and make more effective use of scarce enforcement resources by focusing those resources on the highest regional enforcement priorities. It is anticipated that CMSP implementation through such a cooperative approach will provide greater regulatory certainty and efficiency, which, in turn, would enhance the stewardship of ocean and coastal resources.

The DOI and its various resource management agencies could play a critical role in supporting CMSP and implementation:

- The DOI agencies through their engagement with existing regional ocean councils such as the West Coast Governor's Agreement on Ocean Health (WCGA) could provide valuable support in formation of the Regional Planning Bodies (RPBs), entities that will be charged with regional CMSP effort.

- The DOI agencies and their partners could, through cooperative efforts, also provide data and information to build a regional knowledge base, including information collected by agencies as part of their resource management and stewardship role. The DOI contribution of critical placebased data would be an important contribution to the regional database. Spatial data based on scientific studies and legal protractions are particularly valuable as they could be readily made available in regional data portals to facilitate the decision making. Moreover National Environmental Protection Act (NEPA) reviews also could provide valuable anthropogenic and environmental baseline data and in turn enhance the quality of regional CMS planning exercise.

- DOI agencies such as BOEMRE are engaged continuously in stakeholder outreach to identify leasing blocks for oil and gas and renewable energy development. This process in many ways imitates the stakeholder processes that are at the heart of CMSP. Lessons learned by DOI agencies as well as information on existing stakeholder linkages (particularly tribal linkages) will be informative to the RPBs in their regional stakeholder engagement process. 


\section{Post-Workshop Analysis of Panel Sessions on Day-2}

\section{Working Definition of Coastal and Marine Spatial Planning}

Workshop participants searched for ways to define CMSP in practical terms that did not simply restate the overarching purpose and intent for a comprehensive and proactive approach to managing marine-related activities ${ }^{2}$. Whereas the formal characterization of CMSP is useful to underscore the complexity and scale of marine activities and need for a focused process, it was less clear how regional CMS plans would "look" in tangible terms. The stakeholder engagement process that will bring the diverse voices together in the planning process has yet to be initiated. Also, more work is needed to demonstrate how CMSP will fundamentally differ from ongoing approaches to spatial planning when multiple perspectives and conflicts are involved.

Fundamentally, workshop participants sensed that the clarity needed moving forward will emerge from CMSP becoming a conscious, proactive process rather than the net aggregate of individual and disassociated processes. A general conclusion was that no single protocol or set of instructional steps will encompass the whole intent of CMSP. Rather, CMS planning is essentially a scalable adaptive process for gathering, assessing and interpreting information on alternative uses or future states of the coastal and marine environment. From this perspective, CMSP is less a "thing" that needs to be defined, but more a response sequence to increasing demand for data and information, the steps required to access and apply that data and information, and the complexity of the decisions that will affect it. It is important to recognize that although the CMSP process may address place-based management needs, it also is envisioned under the national policy as a regional scale planning process. Although it may be relevant to specific management areas it will cut across them and consider larger areas and issues.

The challenge and opportunity for DOI and other agencies like NOAA, is to find and leverage the linkages between the broad planning (with data and tools), and the more local mandates that resource managers and others work with on a daily basis. For example, a single national park or national wildlife refuge would not conduct CMSP as envisioned in the Framework; they may undertake a similar process for their own issues and it will be encompassed in the broader regional CMSP when that occurs. The key for scientists and managers is to get engaged in ways that achieve both outcomes.

CMSP will be a stakeholder driven, bottom-up process, in large part driven by regional resource management needs. For example, it is likely that interest in alternative wave energy will be a primary CMSP driver on the West Coast with respect to alternative renewable energy. Although this CMSP planning process is currently (2011) disaggregate, the workshop demonstrated how critical and timely it is - now - to better define it and develop shared understanding and vision among stakeholders.

Flexibility in the planning process will be key to timely implementation of CMSP in the West. The workshop area of focus is huge, and this geography translates to substantial regional differences in ecosystems; natural and cultural resource uses; social, cultural, and economic dimensions; and governmental and stakeholder priorities and engagement. In this regard, the CMSP step-down can be successfully achieved if generalized principles of ecosystem management are used to develop a stakeholder-driven, consensus- and science-based planning framework to implement the national policy (Foley and others, 2010). These authors, and many of their contemporaries, stress the importance of shared goal setting for cumulative effects analysis, ecosystem management, and CMSP, and consideration of ecosystem services as the "common currency" for measuring the effects of human activities and natural variability.

\footnotetext{
${ }^{2}$ See "Final Recommendations of the Interagency Ocean Policy Task Force" (http://www.whitehouse.gov/files/documents/OPTF_FinalRecs.pdf).
} 
Issues of ecological scale are captured in planning concepts such as "Complementary Use," "Context," and "Connectivity" in several layers of the CMSP process presented in figure 1. For natural resource scientists and managers, a primary challenge will be ensuring that sufficient and proper indicators, analytic methods, and evaluation monitoring are developed to functionally support regional objectives of CMSP and adaptive management. Issues of scale, definition of common goals and existing and future conditions, standardization of protocols, data management and integration, and communication must be addressed in early phases of CMSP. Critical aspects for gaining widespread acceptance of CMSP will be through well-articulated strategic goals and objectives, stakeholder involvement, and science-based decision making. There is a clear role for science in CMSP with respect to (1) high-level indicators of ecosystem response; (2) environmental thresholds or "triggers" for adaptive management; (3) data standards and quality assurance; (4) information management system and related tool and model developments; and (5) analysis of cumulative effects (for example, Halpern and others, 2009). Communication, consistency, and collaboration will be hallmarks of successful CMSP and decision making that uses best available science and acknowledges scientific uncertainties.

The DOI mission is to protect and provide access to the Nation's natural resources and cultural heritage and to honor its trust responsibilities to Indian tribes and commitments to island communities. The initial costs for CMSP will be great as the process will require a substantial investment for building partnerships, organizing governance structures, and forming stakeholder networks. In many West Coast areas, especially where states are already developing Geographic Information System (GIS) decision support tools, working relationships already exist. It will be critical for DOI to recognize these relationships and the scientific work of others, early on in the planning process so as to avoid "partner fatigue.”

\section{Commonalities among Perspectives}

Workshop participants recognized that, for the present (2011), no "one size fits all” protocol, database, or decision support technology is available for CMSP. For that reason, in part, workshop objectives focused on first establishing some common information needs for the DOI agencies to assist making recommendations for policy implementation. The plenary and breakout sessions were designed to identify and discuss CMSP science and management information needs and science priorities from large-scale and place-based perspectives along the West Coast Region, across the Pacific Islands, and from Alaska. Several commonalities emerged from these presentations and discussions:

- Stakeholders to the CMSP process in Alaska, West Coast Region, and Pacific Islands include shipping, Defense, industry (for example, energy development), governmental interests, conservation, recreation, fishing, and cultural practice sectors. "Fishing" is an informal umbrella including commercial, recreational, and subsistence harvesting from boat- or shore-based platforms or distant water operations.

- CMSP is a process of identification of the priorities of diverse sets of stakeholders and the information they consider essential, coupled with understanding of the legal framework and subsequent negotiation of spatial use. Because it is highly social and public, it is essential to include social science and cultural experts in development and implementation of CMSP plans. 


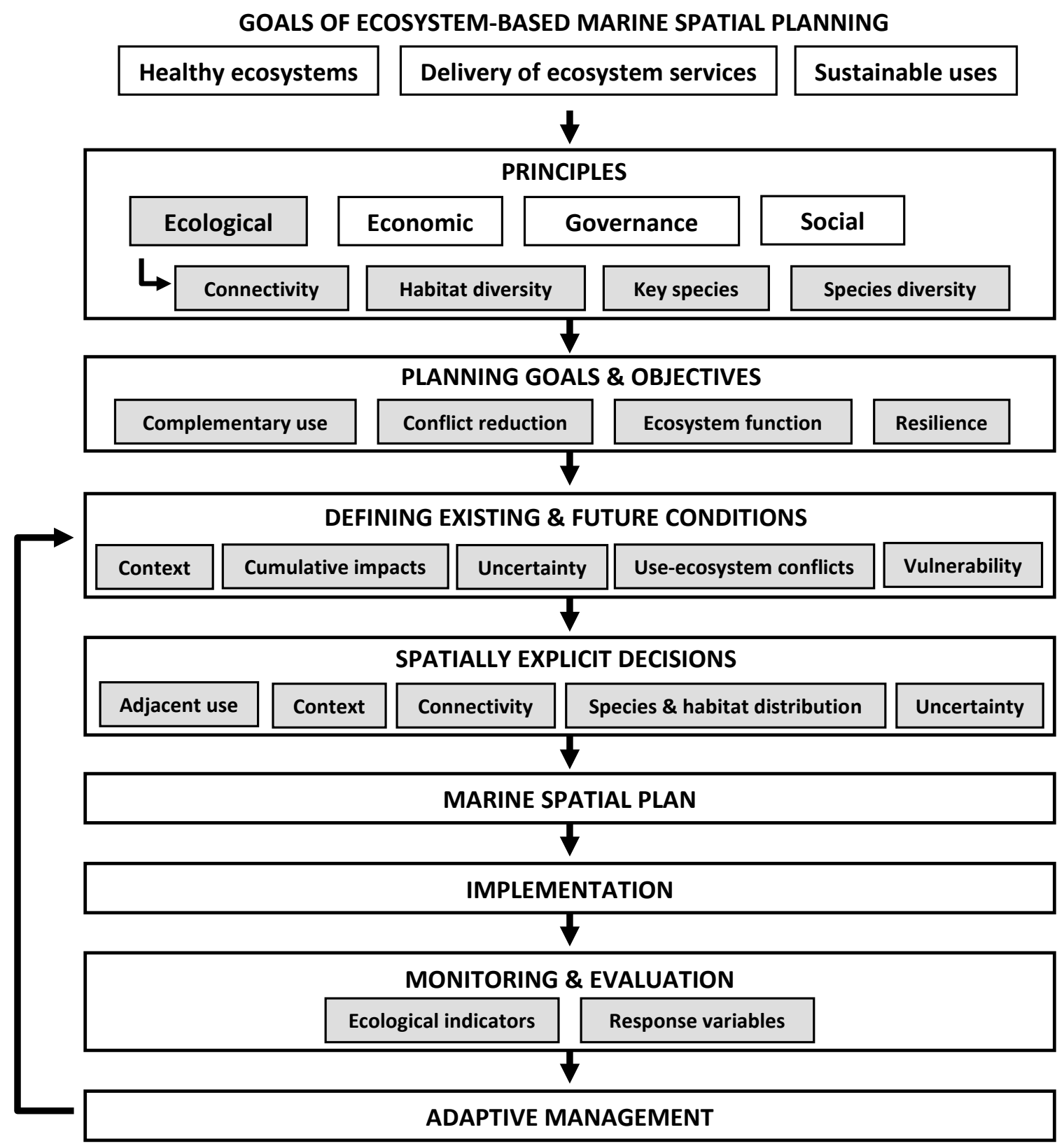

Figure 1. Guiding ecological principles for marine spatial planning (from Foley and others, 2010). 
- Native peoples have strong historical, cultural, spiritual and legal connections with coastal regions and coastal elements in Alaska, the West Coast Region, and Pacific Islands. These groups, which often have treaty-based sovereign rights to the areas and their resources, may base resource management decisions on traditional and current knowledge systems that differ from western scientific systems. Many of these systems are spatially explicit; therefore, in addition to the consultation associated with federally recognized tribes, CMSP should endeavor to include spatial cultural knowledge and traditional ecological knowledge (TEK) in the planning process.

- Agencies and stakeholders need to resolve boundary issues. It generally was recognized that CMSP is, or will be, a resource management tool that is meant to overcome inefficiencies associated with existing administrative and jurisdictional boundaries. Efficiencies gained will be realized in shared agency and public uses of easily accessed data and application tools, increased scientific cooperation and avoidance of duplication, and in resource management that more effectively incorporates scaling effects on environmental variability.

- CMSP with GIS is data-intensive. The data infrastructure demands should not be underestimated, and most DOI agencies will need to equip themselves to participate. That being said, CMSP is happening now and, in most cases, neither Federal nor State agencies have budgets or information technology resources to support full-blown CMSP without additional funds. There may be efficiencies in cooperative development of multi-agency databases and infrastructure, including the emerging National Information Management System being developed by the National Ocean Council (NOC).

- Several agencies addressed the priority of predicting and planning for effects of climate change on sea level, shorelines, erosion, coastal hydrology, ocean acidification, species distributions, food web restructuring, and ecosystem resiliency. There clearly is need for interdisciplinary science to understand and predict possible effects in an ecosystem context that includes human dimensions in addition to physical and biological environments. As such, the CMSP concept dovetails with existing programs in several agencies (for example, National Park Service Inventory \& Monitoring Program, U.S. Fish and Wildlife Landscape Conservation Cooperatives (LCCs), and USGS Climate Science Centers).

- National Park Service, U.S. Fish and Wildlife Service, and Bureau of Land Management are stewards of management units with marine, submerged, and coastal resources. These management units are spatially fixed and thus CMSP is relevant. Importantly, some species for which they are responsible have parts of their life cycles outside of the management units. Moreover, as environmental conditions change, ecotones that shape species distributions may change and are affected by natural processes and disturbances occurring at multiple time and spatial scales. The role of multi-scalar ecosystem science within a CMSP framework was a critical priority for these land-based managers and others at the workshop.

- As national policy is implemented, CMSP will provide a framework for research and assessment with feedbacks for adaptive management. Adaptive management is a systematic approach for achieving identified outcomes through time (Williams and others, 2009). It sets desired conditions, develops monitoring criteria, and identifies thresholds for action when desired conditions are not met. There is a clear role for physical, biological, and socioeconomic science in identifying conditions, thresholds, and monitoring plans for adaptive management.

- Leadership in partnership, collaboration, and coordination in all aspects of CMSP, especially governance structures, is key to the success of the planning process. 
These expressions of common resource management concern easily relate to the ecosystembased planning in figure 1. To varying degrees, the DOI agencies share common goals for sustainability, resource conservation, and societal benefits from ecosystem services (for example, fishing, oil and gas development, subsistence). Ecosystem principles that relate to connectivity, habitat diversity, key species, and species diversity are embedded in many Bureau missions, but were most clearly articulated with respect to climate change effects and management of migratory species. The issue of connectivity transcends ecosystem concepts and, within the CMSP context, offers promise of defeating issues of administrative and jurisdictional boundaries. Just as resource managers are more fully recognizing the value of multi-species approaches, the CMSP process similarly offers improved ways of considering multiple ocean uses and resolving conflicts. Conflicts potentially will arise with differences in the missions of the various agencies or their individual management plans. For example, the NPS emphasizes in its mission statement preservation of resources "unimpaired" for future generations which might preclude proposed activities in a CMSP. The analysis of cumulative human effects is a critical feature of ecosystem management, recognized by all, but, with respect to methodologies, is an area of scientific priority. Although limited by its representativeness, the summary of common concerns demonstrates the aforementioned significance of scale with respect to spatially explicit decision making for place-based land managers.

\section{Science Considerations of Common Interest}

One workshop purpose was to begin a West Coast (Alaska, Pacific Islands, West Coast Region) assessment of DOI regional science needs for CMSP. Because the workshop provided a first introduction to CMSP to many participants, the discussions provided information more about broad thematic needs than specific research questions or information needs. In addition, the workshop focused on three large ecoregions. Specific issues or questions can be expected to vary accordingly by differences in scale, resource issue, and human activities. As a general rule, in presenting these science themes, as CMSP processes down scale from geographic, to regional, and local entities, the requirements for higher resolution data and information will increase dramatically. Understanding the effects of large-scale forcing on local and regional ecosystems is important to DOI managers as well as CMSP priority setting. On the West Coast, for example, one might be evaluating the effects of human activities on valued ecosystem components (for example, fisheries, endangered species) at scales that range from the northeast Pacific Ocean, to the California Current, or in Puget Sound. The location(s) of potential resource conflict(s), availability of existing information, or geographic area where management decisions are made, are other considerations of CMSP priority setting.

\section{Major Science Themes}

\section{Theme 1. Ecosystem Management}

"Ecosystem management integrates scientific knowledge of ecological relations within a complex sociopolitical and values framework toward the general goal of protecting native ecosystems integrity for the long term” (Grumbine, 1994). Thus, there are many principles nested within the concept of ecosystem management that can be addressed within a CMSP frame (fig. 1): biodiversity hierarchy (connections between genes, species, populations, ecosystems, landscapes), ecological boundaries (work across administrative and political boundaries), data collection (science needs and priorities), monitoring and adaptive management, interagency cooperation, organizational change (forming committees to more complex reorganizations), humans as part of the ecosystem, and human values. 
An emerging theme in ecology and oceanography is the importance of cross-ecosystem exchanges (that is, the movement of organisms, materials, or energy from one ecosystem to another). These exchanges, like CMSP, occur at time and spatial scales beyond administrative and jurisdictional boundaries of Federal agencies (that is, piecemeal governance). From a regional perspective, the CMSP process has potential to develop systematic networks of MPAs designed to protect life-cycles of species of concern. At a macro-ecological scale, CMSP offers a planning mechanism that will allow processes and linkages between terrestrial, watershed, coastal, and oceanic effects to be considered in planning and analyses, along with a policy framework that encourages multi-institutional collaboration to characterize and incorporate these exchanges in CMS plans.

Theme 2. Cumulative Effects

Cumulative effects are the combined, incremental effects of human activities. Cumulative effects can result from factors that may not be important by themselves, but are substantial when interacting or accumulating through time and space, through repetition, or from a combination of other effects. When actions are considered individually or independently, their combined consequences may not be fully considered or evaluated. This results in not understanding or anticipating the long-range effects of multiple decisions over large areas. There is a pressing need for methods to evaluate the cumulative effects of human activities, and CMSP provides a scientific framework for the iterative analytical process that will be required to visualize these effects.

\section{Theme 3. Social Sciences / Traditional Ecological Knowledge}

CMSP is a stakeholder-driven process. Social and TEK science resources are highly relevant to informing the CMSP process at regional and, especially, local levels. Importantly, traditional (indigenous) ecological knowledge and resource management is place-based, readily incorporated into CMSP. Traditional economies often are based on subsistence and the seasonal round. Subsistence reflects a multi-disciplinary resource use that can include sustenance and cultural dimensions of barter and kinship. Subsistence information can complement existing scientific information and assist science priority setting and conflict resolution within the CMSP framework. The protection of cultural lifestyles is an important DOI role and this stakeholder group must be fully represented in CMSP.

\section{Theme 4. Achieving Scientific Efficiencies Through Improved Coordination and Cooperation}

Many DOI agencies would benefit from greater access to scientific data and information and learning how their activities could contribute information gathering, greater ecosystem understanding, and improved natural and cultural resource management. Science needs in various bureaus primarily are driven by operational and statutory considerations such as understanding changing ecological conditions because of climate change, or leasing offshore energy and mineral resources. There are considerable science and data gaps; CMSP is an opportunity to identify and potentially lead partners or collaborators to leverage their resources to fill these gaps. 
CMSP offers the potential to evaluate the existence of scientific overlap in agency missions or, if necessary, expand the scope of bureau-specific missions to better serve CMSP goals for DOI. In the short-term, there needs to be a concerted effort to inventory and understand what data, tools, and technologies exist or are planned. An Interior committee is beginning this process and, with respect to ocean roles, NOAA (National Ocean Service, National Marine Fisheries Service) should be key nonDOI partners in this strategic planning.

- $\quad$ Linkages with existing initiatives: Creating linkages between CMSP and existing science and data initiatives such as the LCC will help leverage resources, reduce redundancy, and avoid the partner/stakeholder fatigue issue. Scientifically, ecological linkages between watershed, land-sea interfaces, and, at least, coastal ocean connections should be included in CMSP implementation.

- Data integration: A need was identified to develop tools and platforms for seamless sharing of data and information among DOI bureaus. This could involve developing new tools, or enhancing the operability of existing tools such as the Multipurpose Marine Cadastre (see appendix 5) or other systems used by western states (for example, MarineMap). Data integration efforts should be tuned to serve the operational needs of the RPBs.

\section{Theme 5. Implementation and Scale}

The scope and intensity of assembling and analyzing information is driven by the complexity of decisions at hand and the availability of information (science and local knowledge) needed to provide sufficient foundation for those decisions. CMSP defined as a scaled, rather than rigid, process may help clarify the relation between existing approaches to supporting the decision process and the construct we are building toward. To illustrate, consider three levels of decision complexity and the manner in which CMSP functions to provide science underpinnings:

- Under the "least complex circumstances," a framework for decision-making is already in place and the information needed to make the decision is readily available. There may not be a need to further enhance the assembly and analysis of information beyond what already has been shown to work well. Under these routine conditions, CMSP may simply be a reflection of the ongoing approach, if it is invoked at all.

- Under "increasingly demanding circumstances," the information needed to support the decision process may exist, but is not readily accessible or integrated to the degree necessary. CMSP may play the pivotal role in location, assembly and integration of the needed information, whereas it would otherwise remain unobtainable. The tangible dimensions of CMSP in this case include securing access to existing information and putting it in a form that is usable, whether it is to describe the present state or predict future conditions.

- Under "the most complex circumstances," not only are some or all of the information needed unavailable to decision makers, but they do not exist. CMSP would then involve not only gathering available information, but also assessing the knowledge gaps and addressing the science needs to fill those gaps. Matters of scale, timing, resolution, and ability to integrate information and participant involvement would be part of a large scale planning process. 


\section{Recommendations}

The 2-day West Coast CMSP Workshop convened a key group of DOI and non-DOI participants with roles in ocean science and resource management. The engagement resulted in a firstorder synthesis of information with respect to developing a common understanding of CMSP from DOI perspectives. Importantly, it also led to the identification of broad science and data needs that can be critically addressed in future regional planning. Future planning can use the ecosystem management principles and science areas identified herein to refine CMSP planning at more appropriate geographic scales nested within our West Coast designation. It is important, at the regional scale, to begin a much more dedicated effort to educate and inform DOI and key partners about CMSP as soon as possible and, a special team may be needed to serve this function.

The information presented at this workshop can guide CMSP planning processes and implementation of the National Ocean Policy at all organizational levels of the Federal government. As an example, the national CMSP conference, presently scheduled to be held in June 2011, has similar objectives to this West Coast workshop. The national meeting will address similar issues on a largerscale and will include stakeholder engagement from across nine DOI regions. In this context, the "lessons learned" from this workshop are highly relevant to priority "next steps" and should be considered by others as they engage in the CMSP initiative. A concensus from the workshop indicated "next steps" to include:

1. Leadership entities should identify stakeholders and information resources (appendix 6) to develop regional governance structures and initiate policy.

2. Create data inventory and explore data integration with Federal agencies and others (for example, State agencies) engaged in CMSP or similar process. As an example, the States of Washington, Oregon, and California are engaged in CMSP and are using MarineMap geospatial technology.

3. Require enhanced cooperation among Federal agencies to facilitate information and resource sharing. This will avoid duplication and redundancy, increase scientific and resource management efficiencies, and reduce costs through leveraged scales of economy.

4. Highlight the role of science in conflict avoidance and conflict resolution.

5. Include TEK in CMSP and DOI scientific planning processes.

6. Identify and explore potential streamlining in regulatory and management processes that will occur through CMSP (for example, environmental impact assessment requirements for renewable energy development on the Outer Continental Shelf).

\section{Final Statement}

Substantial progress was made in developing common understanding about CMSP and what its successful implementation might require. Important linkages between resource management and science needs in CMSP were identified and will be critical to future planning. Some concluding points include:

1. The initial West Coast CMSP Workshop represents the beginning of a planning process that requires additional "in reach" within DOI, and "outreach" with DOI partners and regional stakeholders. The West Coast Region (California, Oregon, and Washington) geography and regional differences are such that individual planning efforts for the West Coast Region, Pacific Islands, and Alaska are recommended. 
2. There will be challenges for all Federal agencies in implementing National Ocean Policy at regional and local levels, including coordination at Federal and State levels. In some instances, State natural resource scientists and managers are already involved in CMSP related activities. In these instances, RPBs or task forces are urgently needed to establish effective partnerships that will ensure data sharing, system interoperability, identify and engage key stakeholders, and benefit from others about their "lessons learned" in CMSP.

3. Ecosystem-based management is a strategic goal of CMSP. This planning, if properly undertaken, should abide by principles identified herein with benefit to DOI through:

- Increased relevance and versatility of natural and cultural resource science to resource management and policy making;

- provision of a conceptual foundation to evaluate existing data and information, assess threats and vulnerabilities, and identify major gaps in knowledge and understanding;

- provision of a planning framework for collaboration to address priority information needs through application of landscape principles, multi-scalar approaches, and cooperation with existing programs; and

- increased opportunities for data and cost sharing and streamlining of environmental/regulatory processes.

4. Boundaries and cumulative effects. The results of defined common goals, data sharing, and cumulative impact analysis should contribute to refining alternatives and designing mitigation techniques and approaches.

5. Monitoring environmental change and the accuracy of predictions is an important part of the ecosystem response and cumulative effects analysis. CMSP requires feedback loops for adaptive management in a science-based information planning process.

\section{Acknowledgments}

The authors would like to acknowledge the contributions of Michael Carr, David Woodson, Christina Neal, Carl Markon, Eric Grossman, and Lief Horwitz for the organization and planning of the workshop. Our special thanks to all the workshop presenters and participants who shared information about Department of the Interior and other Federal agency missions in natural resource science and management, existing policies and programs, regional information needs, and understanding of Coastal and Marine Spatial Planning. Their contributions to the workshop provided an important forum to bridge national and regional requirements and further enhance working relationships within the DOI, with other Federal agencies, and with other stakeholders. Finally, we thank three anonymous reviewers for their comments on the draft proceedings report. Their comments added greatly to the overall content and quality of this report. 


\section{References Cited}

Federal Register, vol. 75, No. 140, Thursday, July 22, 2010.

M.M. Foley, B.S. Halpern, F. Micheli, M.H. Armsby, M.R. Caldwell, C.M. Crain, E. Prahler, N. Rohr, D. Sivas, M.W. Beck, M.H. Carr, L.B. Crowder, J.E. Duffy, S.D. Hacker, K. McLeod, S.R. Palumbi, C.H. Peterson, H.M. Regan, M.H. Ruckelshaus, P.A. Sandifer, R.S. Steneck, 2010, Guiding ecological principles for marine spatial planning. Marine Policy 34(5): 955-966. doi: 10.1016/j.marpol2010.02.001.

Grumbine, R.E., 1994, What is ecosystem management? Conservation Biology v. 8, no. 1, p. $27-38$. Halpern, B.S., and others, 2009, Mapping cumulative human impacts to California Current marine ecosystems:. Conservation Letters 2, p. 138-148.

Williams, B.K., R.C. Szaro, and C.D. Shapiro, 2009, Adaptive Management: The U.S. Department of the Interior Technical Guide. Adaptive Management Working Group, U.S. Department of the Interior, Washington, DC.

\section{Glossary}

$\begin{array}{ll}\text { BOEMRE } & \text { Bureau of Ocean Energy Management Regulation and Enforcement } \\ \text { CEQ } & \text { Council on Environmental Quality } \\ \text { CMSP } & \text { Coastal and Marine Spatial Planning } \\ \text { DOC } & \text { Department of Commerce } \\ \text { DOI } & \text { Department of the Interior } \\ \text { GIS } & \text { Geographic Information System } \\ \text { LCCs } & \text { Landscape Conservation Cooperatives } \\ \text { MMC } & \text { Multipurpose Marine Cadastre } \\ \text { MPAs } & \text { Marine Protected Areas } \\ \text { NEPA } & \text { National Environmental Policy Act } \\ \text { NOAA } & \text { National Oceanic and Atmospheric Administration } \\ \text { NOC } & \text { National Ocean Council } \\ \text { NPS } & \text { National Park Service } \\ \text { RFMC } & \text { Regional Fisheries Management Councils } \\ \text { RPBS } & \text { Regional Planning Bodies } \\ \text { TEK } & \text { Traditional Ecological Knowledge } \\ \text { USGS } & \text { U.S. Geological Survey }\end{array}$




\section{Appendix 1. Précis of the National Ocean Policy Concept and Process}

On July 19, 2010, President Obama signed Executive Order 13547, which establishes the Nation's first comprehensive National Policy for the stewardship of the ocean, our coasts, and the Great Lakes. The establishment of a policy was recommended by the U.S. Commission on Ocean Policy in 2004. The National Policy adopts the 'Final Recommendations' of the Interagency Ocean Policy Task Force and directs Federal agencies to take steps to implement the recommendations. Additionally, it creates an interagency National Ocean Council (NOC) comprising 27 agencies, offices, and departments to strengthen ocean governance, and provides sustained, high-level focus on the national priority objectives identified in the Final Recommendations for action to advance the National Policy.

The National Policy identifies nine proposed regional planning areas and corresponding State representation:

- Alaska /Arctic Region: Alaska

- Caribbean Region: Puerto Rico and U.S Virgin Islands

- Great Lakes Region: Illinois, Indiana, Michigan, Minnesota, New York, Ohio, Pennsylvania, and Wisconsin

- Gulf of Mexico Region: Alabama, Florida, Louisiana, Mississippi, and Texas

- Mid-Atlantic Region: Delaware, Maryland, New Jersey, New York and Virginia

- Northeast Region: Connecticut, Maine, Massachusetts, New Hampshire, Rhode Island, and Vermont

- Pacific Islands Region: Hawaii, Commonwealth of the Northern Mariana Islands, American Samoa, and Guam

- South Atlantic Region: Florida, Georgia, North Carolina, and South Carolina

- West Coast Region: California, Oregon, and Washington

The National Ocean Council would work with the States and federally recognized tribes, including Alaska Native Villages, to create regional planning bodies-coinciding with the regional planning areasfor the development of regional Coastal and Marine Spatial Plans (CMSP). The membership of each of the nine regional planning bodies would consist of Federal, State, and tribal authorities relevant to CMSP for that region (for example, resource management, including coastal zone management and fisheries management, science, homeland and national security, transportation, and public health). In addition, the regional planning bodies would provide a formal mechanism for consultation with the Regional Fishery Management Councils (RFMCs) across their respective regions on fishery-related issues given their unique statutory responsibilities under the Magnuson-Stevens Fishery Conservation and Management Act (Magnuson-Stevens Act) and quasi-regulatory role in fisheries management. Each regional planning body should make every effort to ensure representation from all States within a region, ideally through, or as part of, the existing regional governance structures created by or including the States to address cross-cutting issues, including regional planning. Given that activities that happen outside of the planning area of each regional planning body may affect CMSP decisions in that area, ex officio membership on these bodies could be extended to adjacent coastal States to help integrate and enhance consistency among regions. Inland States may also be afforded membership, as determined appropriate by the regional planning body. It is also recognized that the United States shares maritime boundaries with other nations and the regional planning bodies for those respective areas may include ex officio representatives or observers from these nations. 
The NOC would review each regional CMS Plan to ensure it is consistent with the National Policy, CMSP goals and principles as provided in this framework, any national objectives, performance measures, or guidance the NOC has articulated, and any other relevant national priorities. The NOC's review would ensure that the CMS Plans include all the essential elements described in this framework. The NOC also would consider the CMS Plan's compatibility with an adjacent region's CMS plan regarding issues that cross regional boundaries. Certification by the NOC would not occur until after release of the final CMS Plan for 30 days of public notice. The NOC would review and make a decision on certification within 6 months of receipt of the CMS Plan. If a regional CMS Plan does not meet certification requirements, the NOC would work with the regional planning body to address issues with the CMS Plan and could allow for approval of those parts of a CMS Plan that do meet such requirements. Upon certification by the NOC, a decision document adopting the CMS Plan would be co-signed by senior State officials (for example, Governors), tribal representatives, as appropriate, and senior officials of the Federal agencies represented on the regional planning body. Upon signature by the partners, the CMS Plan would be considered "in effect” and implementation would begin. Signatories and all NOC member agencies would adhere to a NOC-certified CMS Plan, within the limits of their existing statutory and regulatory authorities. If a signatory intends to take an action that does not substantially adhere to a certified CMS Plan, it would need to provide advance notice to the regional planning body and the NOC, including justification for the non-adherence. The CMS Plan signatories and the NOC would periodically evaluate the reasons requiring deviation from a NOCcertified CMS Plan, and, as appropriate, develop recommendations for minimizing these deviations in the future, including CMS Plan modification or underlying regulatory or statutory changes. Disputes regarding agency interpretation of a CMS Plan would be resolved according to the dispute resolution process developed by the NOC, as described above.

Agencies would incorporate components of the CMS Plan into their respective regulations to the extent possible. Adherence with CMSP would be achieved through Federal and State agencies and tribal authorities incorporating CMS Plans into their pre-planning, planning, and permitting processes, to the extent consistent with existing laws and regulations. The CMS Plan signatories would periodically review these processes, and where legal constraints are identified, would seek to remedy these constraints, including by working with the NOC to evaluate whether a legislative solution or changes to regulations are necessary and appropriate.

The effectiveness of the CMSP process depends, in part, on the willingness and the ability of Federal, State, and tribal authorities to ensure that activities of third-parties are in compliance with relevant laws and regulations. The Nation would not achieve the benefits of comprehensive and integrated CMSP if there were inconsistent use or violation of the applicable laws and regulations. Successful enforcement, carried out by agencies exercising their individual enforcement authorities and responsibilities, must be based upon clear, concise, and easily understood requirements that reflect the practical realities of compliance and enforcement. 


\title{
Appendix 2. Invitation to Participate
}

\author{
August 24, 2010 \\ December 1-2, 2010 (San Francisco Bay Area, CA) \\ Sponsored and hosted by USGS and BOEMRE
}

The release of the White House Council on Environmental Quality's Final Recommendations of the Interagency Ocean Policy Task Force (http://www.whitehouse.gov/files/documents/OPTF_FinalRecs.pdf) on July 19, 2010, has prompted renewed national focus on the importance of science-based planning for coastal issues. Alongside a large collection of other participants, the Department of Interior will play a significant role in realizing the implementation of the Framework for Effective Coastal and Marine Spatial Planning (CMSP) guidelines included in the CEQ report. Within DOI, the perspectives and priorities for the development and application of CMSP are expected to vary with individual agency missions but will undoubtedly share fundamental needs for science-based information and communication. In order to promote discussion of CMSP within DOI as a preparatory step toward subsequent national and regional engagement, the U. S. Geological Survey and the Bureau of Ocean Energy Management, Regulation and Enforcement are convening a CMSP workshop to share these ideas and promote our collective understanding of science needs.

The two-day workshop, to be held December 1-2, 2010 in the San Francisco Bay Area, will convene representatives from DOI offices and other groups actively engaged in CMSP. We will discuss current activity and future directions for CMSP through presentations, discussions, and breakout sessions along with an evening poster/demonstration session. We will build on the national direction to address geographical considerations for the West Coast and Pacific Islands and begin to identify the range of concerns across DOI offices. The aim of the workshop is to promote better understanding within DOI for CMSP directions on the West coast and in Alaska, Hawaii, and the Pacific Islands, and provide a model that may be applied in other geographical settings.

We invite your participation in this effort to develop regional expression of CMSP and to build understanding of DOI management concerns that will drive its application. We are including a small number of key presenters from outside DOI in order to help frame the national context and provide input based on their experience. Your participation will contribute important perspectives as we address CMSP issues and road maps for progress.

Attached you will find a preliminary agenda for the workshop. Individual participants will be invited to speak in separate communications. Details regarding travel, logistics and agenda refinements will be forthcoming. Please RSVP online by visiting this web site: http://www.doodle.com/b3givpsqrugx485k

If you have questions or need more information, please contact the workshop planning co-chairs. And, if there is someone else in your organization that you wish to recommend attend in your place, we welcome your suggestions. On behalf of the Workshop Planning Group, we are genuinely excited by the challenges and opportunities ahead. We look forward to working with you.

Richard Ferrero, Co-Chair, Workshop Planning Group

Acting-Regional Director, Western Region

U.S. Geological Survey

206-220-4578rferrero@usgs.gov

Joan Barminski, Co-Chair, Workshop Planning Group

Deputy Regional Director, Pacific OCS Region

Bureau of Ocean Energy Management, Regulation and Enforcement

805-389-7509 joan.barminski@boemre.gov 


\section{Appendix 3. Agenda}

\section{Exploring DOI Science Needs in the West-A Workshop Co-Hosted by USGS and BOEMRE}

\section{Day 1 -Learning About CMSP}

8:30 Welcome and Expectations (45 min.) Suzette Kimball, Deputy Director, U.S. Geological Survey

Deanna Archuleta, Deputy Assistant Secretary for Water and Science, Department of the Interior Alan Thornhill, Science Advisor to the Director, Bureau of Ocean Energy Management, Regulation and Enforcement Terry Holman, Ocean and Coastal Activities Coordinator, Department of the Interior

\section{Part 1a: National Perspectives on CMSP Inside DOI}

9:15 National Goals for CMSP (25 min.) Mary Boatman, Ocean Policy Advisor, National Ocean Council Staff

9:40 DOI Representatives to CMSP Working Group (45 min.) Science Focus: John Haines, USGS Management Focus: Renee Orr, BOEMRE

10:25 Break (20 min.)

\section{Part 1b: National Perspectives on CMSP outside DOI}

10:45 NOAA Perspective and Strategy for CMSP (25 min.)

Charles Wahle, NOAA

11:10 The Role of Non-Governmental Organizations (25 min.) Michael Beck, Nature Conservancy

11:35 Implementation of CMSP (25 min.) Meg Caldwell, Stanford University, Center for Ocean Solutions

12:00 Academic Partners (25 min.) Dave Fluharty, University of Washington

12:25 Lunch (60 min.)

Day 1 Part 2: Western Perspectives on CMSP: Panel Discussion and Case Studies

1:30 CMSP and DOI Resource Managers from Across the West (75 min.) Panel discussion: NPS, FWS, BLM, BOEMRE, BIA NPS -Ray Sauvajot, NPS Chief National Resources PW Region FWS -Mendel Stewart, USFWS, San Francisco Bay National Wildlife Refuge BLM -Rick Hanks, California Coastal National Monument Manager BOEMRE -Ellen Aronson, Regional Director, Pacific OCS BIA - Bryan Rice, Assistant Director, Resource Protection, Division of Forestry MODERATOR: Lyman Thorsteinson, USGS

2:45 Break (30 min.) 


\section{Case Studies}

3:15 West Coast Case Study (30 min.)

Will McClintock, University of California Santa Barbara

3:45 Hawaii and the Pacific Islands Case Study (30 min.)

Alan Friedlander, USGS Cooperative Fisheries Research Unit, University of Hawaii at Manoa

4:15 Alaska Case Study (30 min.)

TBD

4:45 Closing Comments, Invitation to Poster Session, and Preview of Day 2

Joan Barminski, BOEMRE

6:00 Networking \& Demo/Poster Session

Day 2-Science in Support of DOI Regional Priorities

8:30 Recap of Day 1 and Setting the stage for Day 2 (20 min.)

Rich Ferrero, USGS

\section{Part 3: Science Considerations of Common Interest}

9:00 Overarching Science and Operational Considerations (Panel Discussion) (60 min.)

NPS -Jeff Mow, NPS

FWS -Carol Schuler, USFWS/USGS

BLM -Jim Weigand, BLM

BOEMRE -Ann Bull, BOEMRE

USGS-Sam Johnson, USGS

BIA - Bryan Rice, BIA

MODERATOR: Amardeep Dhanju, BOEMRE

10:00 Charge to Breakouts (15 min.)

Joan Barminski, BOEMRE

10:15 Break (25 min.)

\section{Part 4: Regional Science Priorities in Western Regions}

10:40 Breakout Session 1: DOI Science Needs/Issues for CMSP by Area (60 min.)

Three Groups: Alaska, Washington+Oregon+California, and Hawaii+Pacific Islands

FACILITATORS:

Alaska - Cathy Coon, BOEMRE

Washington, Oregon, California -Curt Storlazzi, USGS and Sam Johnson, USGS (2 groups)

Hawaii+Pacific Islands -Dave Helweg, USGS

11:40 Breakout Session 1 Report Out (20 min.)

12:00 Lunch (60 min.) 
Part 5: Identifying DOI Priorities in the West

1:00 Charge to Breakouts (10 min.)

Joan Barminski, BOEMRE

1:10 Breakout Session 2: CMS Science Needs/Priorities by DOI Office (60 min.)

Five Groups: BOEMRE, NPS, FWS, BLM, BIA

FACILITATORS:

NPS -Sarah Allen

FWS -Erin Stockenberg

BLM - Julia Dougan

BOEMRE - Jaron Ming

BIA - Bryan Rice

2:10 Break (30 min.)

2:40 Breakout Session 2 Report Out (30 min.)

Part 6: What have we Learned and Formulating Next Steps

3:10 Summary Discussion and Next Steps (Panel-led Discussion) (90 min.)

Rebecca Smyth, NOAA and WCGA

Alan Friedlander, University of Hawaii and USGS

Joel Reynolds, USFWS

Rodney Cluck, BOEMRE

Mary Boatman, Ocean Policy Advisor, National Ocean Council Staff

John Haines, USGS

Facilitator of Discussion: Joan Barminski, BOEMRE and Rich Ferrero, USGS

4:40 Closing Remarks 


\section{Appendix 4. List of Attendees}

Confirmed Participants as of November 15, 2010

Joan Barminski, BOEMRE

Renee Orr, BOEMRE

Jeffrey Mow, NPS

Amardeep Dhanju, BOEMRE

Ellen Aronson, BOEMRE

Maurice Hill, BOEMRE

Jaron Ming, BOEMRE

Ann Bull, BOEMRE

Lynnette Vesco, BOEMRE

Rodney Cluck, BOEMRE

Michael Rasser, BOEMRE

Alan Thornhill, BOEMRE

Cathy Coon, BOEMRE

Jully McQuilliams, BOEMRE

Trent Richardson, BOEMRE

Drew Mayerson, BOEMRE

Stephanie Rozek, BOEMRE

John Romero, BOEMRE

Suzette Kimball, USGS

Richard Ferrero, USGS

John Haines, USGS

Mike Carr, USGS

Lyman Thorsteinson, USGS

Leslie Dierauf, USGS

Tony DeGange, USGS

Mike Shulters, USGS

Dave Helweg, USGS

Lief Horwitz, USGS

Eric Grossman, USGS

Carl Markon, USGS

Gordon Tribble, USGS

Sam Johnson, USGS

Mark Fornwall, USGS

Steven Schwarzbach, USGS

Tom Suchanek, USGS

Tina Neal, USGS

Curt Storlazzi, USGS

Dave Woodson, USGS

Mary Irvine, USGS

Sarah Allen, NPS

Ray Sauvajot, NPS

Marc Webber, USFWS

Cynthia Jacobson, USFWS

Joel Reynolds, USFWS

Richard Kearney, USFWS

Mendel Stewart, USFWS

Chris Swenson, USFWS

Carol Schuler, USFWS

Erin Stockenberg, USFWS

Julia Dougan, BLM

Rick Hanks, BLM

Jim Weigand, BLM

Bryan Rice, BIA

Chad Wallace, BIA

Alan Friedlander, University of HI and USGS

David Fluharty, University of Washington

Meg Caldwell, Stanford University

Will McClintock, UC Santa Barbara

Michael Beck, The Nature Conservancy

Jena Carter, The Nature Conservancy

Charles Wahle, NOAA

John Stein, NOAA

Becky Smyth, NOAA

Amy Holman, NOAA

Dave Lott, NOAA

Sean Hastings, NOAA

Simon Geerlofs, DOE

Mary Boatman, OSTP

Terry Holman, DOI

Deanna Archuleta, DOI 


\section{Appendix 5. Multipurpose Marine Cadastre (MMC)}

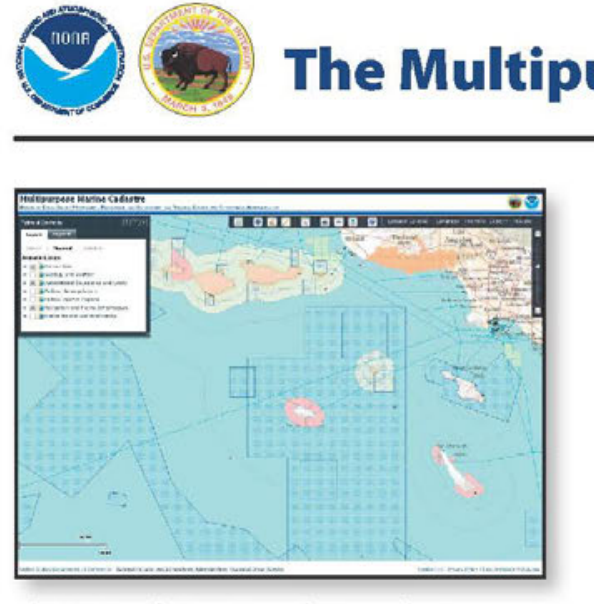

The National Oceanic and Atmospheric Administration and the Bureau of Ocean Energy Management, Regulation and Enforcement, in cooperation with federal and state partners, have created a GIS-based marine information system for the U.S. waters.

The Multipurpose Marine Cadastre is an integrated marine information system that provides legal, physical, ecological, and cultural information in a common geographic information system (GIS) framework. All organizations considering an offshore activity can benefit from this comprehensive, visual approach to data analysis. This tool was created to comply with Section 388 of the Energy Policy Act of 2005, but is also providing the geospatial framework needed for the broader coastal and marine spatial planning initiative called for in the President's ocean agenda.

\section{Audience}

This tool is used by federal regulatory agencies and others who are screening renewable energy sites and other offshore activities. The tool is also being used by people working on regional and state coastal and marine spatial planning efforts.

\section{Authoritative and Trusted Data Source}

At its core, this data viewer contains the official U.S. marine cadastre, and is the only place where users can see all of the official U.S. boundaries on one map. Similar to the nation's land-based parcel system, a marine cadastre describes the spatial extent, rights, restrictions, and responsibilities of U.S. waters. All data come from the appropriate authoritative source; these organizations are responsible for data upkeep.

\section{Future Direction}

The system is constantly evolving and growing to include relevant issue-driven data, and in the future, the project team will focus on strengthening the biodiversity and human use data, as well as building decision support tools to support coastal and marine spatial planning.

\section{Technological Innovation}

The Multipurpose Marine Cadastre project takes advantage of the data distribution advances provided by web services, a technology that allows data to reside on servers maintained by the authoritative data sources, and yet these same data can be accessed on demand through the Multipurpose Marine Cadastre.

State and regionally driven coastal and marine spatial planning initiatives can connect to the Multipurpose Marine Cadastre and be confident in having the most accurate federal data available. This innovative system provides tremendous efficiences for all levels of government and contributes to a national coastal and marine spatial planning framework.

\section{Project Leads}

- Bureau of Ocean Energy Management, Regulation and Enforcement

- NOAA Coastal Services Center

\section{Current Partnerships}

- NOAA Fisheries

- NOAA Office of Marine Sanctuaries

- NOAA Office of Coast Survey

- NOAA Office of Ocean and

Coastal Resource Management

- U.S. Fish and Wildlife Service

- The Nature Conservancy

- California Coastal Conservancy

- Federal Energy Regulatory Commission

- U.S. Coast Guard

- U.S. Geological Survey

- Department of Defense

- Department of Energy

\section{Partnership Opportunities}

- Regional Ocean Councils and Coastal States

- IOOS Regional Associations

- Private Sector 


\section{The Multipurpose Marine Cadastre currently includes the following data themes}

\author{
Jurisdictional Boundaries and Limits \\ Revenue Sharing Boundary \\ Territorial Sea Boundary \\ Contiguous Zone \\ Exclusive Economic Zone \\ Submerged Lands Act Boundary \\ Federal Fishery Management Areas \\ National Estuarine Research Reserves \\ National Marine Sanctuaries \\ Marine National Monuments \\ Coastal Forest, Parks, and Refuges \\ Coastal Indian Lands \\ Coastal Barrier Resources Act Zones \\ BOEM Protractions Diagrams \\ BOEM OCS Lease Blocks \\ BOEM Planning Areas \\ BOEM Administrative Boundaries \\ State MPAS \\ Atlantic OCS Wind Energy Areas
}

Federal Georegulations

Abandoned Shipwreck Act

Clean Water Act

Coastal Zone Management Act

Endangered Species Act

Marine Debris Research, Prevention, and Reduction Act

Marine Mammal Protection Act

Marine Plastics Pollution Research and Control Act

Magnuson-Stevens Fishery Conservation Act

National Environmental Policy Aict

Outer Continental Shelf Lands Act

Submerged Lands Act

\section{Federal Agency Regions}

Federal Agency Regions, Districts, and Planning Areas

Regional 0 cean Council Boundaries

US/Canada Great Lakes Boundary

Navigation and Marine Infrastructure

Shipping

Collision Regulations Boundary

Oil and Natural Gas Wells

Drilling Platforms

Liquefied Natural Gas Wells

Selected Pipelines

Submarine Cables

Anchorage Areas

Military Danger Zones

Aids to Navigation
Physical and Oceanographic

OCSS and and Gravel Borrow Areas

Bathymetry Contours (selected areas)

Offshore Wind Resource Potential

Atlantic, Pacific, and Gulf of Mexico Offshore Surficial Sediment

Atlantic and Gulf of Mexico Seafloor Geology

36-meter Depth Contour

Human Use

BOEM Active 0il \& Gas Leases

BOEM Active Renewable Energy Leases

Proposed California Hydrokinetic Sites

Marine Habitat and Biodiversity

Gray Whale Migration (California, Not Official)

Pinniped Haul Outs and Rookeries (California)

Rocky Reefs (California)

Kelp Canopy (California)

Seagrass Beds (California)

Groundfish Essential Fish Habitat (California)

NMFS Essential Fish Habitat

NMFS Critical Habitat

NMFS Habitat Areas of Particular Concern

Additional Webmap Services

and ArcGIS Servers

Marine-Geo.org Bathymetry WMS Service

U.S. Marine Cadastre WMS Service

For additional information:

www.marinecadastre.gov

Christine Taylor - Lead Physical Scientist

Bureau of Ocean Energy Management, Regulation, and Enforcement

E-mail: Christine.Taylor@boemre.gov

Phone: (703) 787-1606

David Stein - Geographer

NOAA Coastal Services Center

E-mail:Dave.Stein@noaa.gov

Phone: (843) 740-1310 


\section{Appendix 6. CMSP Resources and Links}

Articles and Upcoming Events

http://www.cmsp.noaa.gov/news.html

National Ocean Policy

http://www.whitehouse.gov/administration/eop/ceq/initiatives/oceans

Meeting Today's Ocean, Coastal, and Great Lakes Challenges

http://www.doi.gov/initiatives/ocean.html

Marine Spatial Planning - MMS (BOEMRE) and the Ocean Policy Task Force Framework at an OCS workshop held January 20, 2010:

http://www.ocsadvisoryboard.org/files/workshops/2010/2.pdf

Final Recommendations of the Interagency Ocean Policy Task Force from the White House Council on Environmental Quality July 19, 2010:

http://www.whitehouse.gov/files/documents/OPTF_FinalRecs.pdf

Marine Spatial Planning Stakeholder Analysis conducted for the NOAA Coastal Service Center by the Eastern Research Group (ERG), Lexington, MA January 22, 2010:

http://www.csc.noaa.gov/publications/MSP_Stakeholder_Analysis.pdf

Arctic Coastal and Marine Spatial Planning and the Role of the Arctic People co-sponsored by the

Alaska Eskimo Whaling Commission and the Environmental Law Institute March 11, 2020 in

Washington, DC:

http://www.eli.org/seminars/event.cfm?eventid=539

Alaska Ocean Observing System (AOOS) Workshops and Reports August 2010:

http://www.aoos.org/about/workshops.html

The National Oceanic and Atmospheric Administration (NOAA) announced in the September 13, 2010

Federal Register the availability of a competitive federal funding opportunity (FFO) for Regional Ocean Partnerships (ROP). Information regarding the FFO can be found at:

http://www.csc.noaa.gov/funding/

There is also a Federal Register Notice:

http://www.gpo.gov/fdsys/pkg/FR-2010-09-13/html/2010-22645.htm 
Publishing support provided by the U.S. Geological Survey

Publishing Network, Tacoma Publishing Service Center

For more information concerning the research in this report, contact the

Director, Western Fisheries Research Center

U.S. Geological Survey

6505 NE 65th Street

Seattle, Washington 98115

http://wfrc.usgs.gov/ 
2.

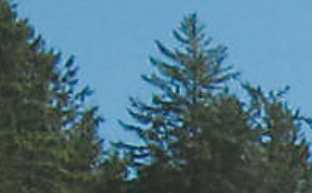

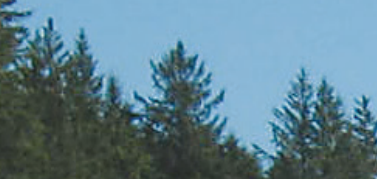

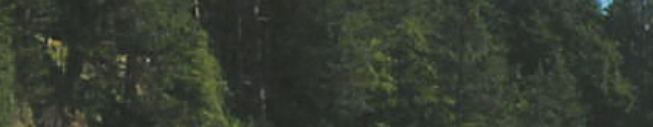

$x^{2}+x^{2}+2 x$

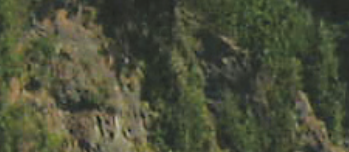

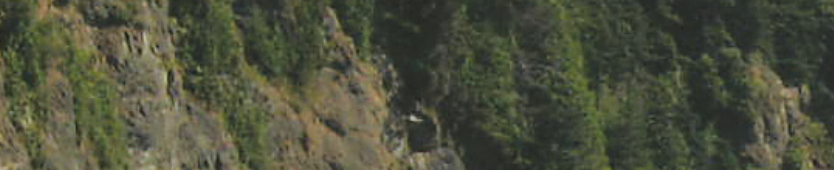

(b)

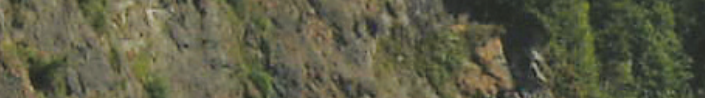

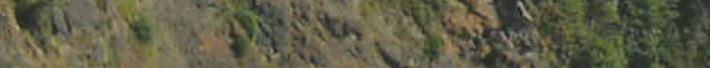

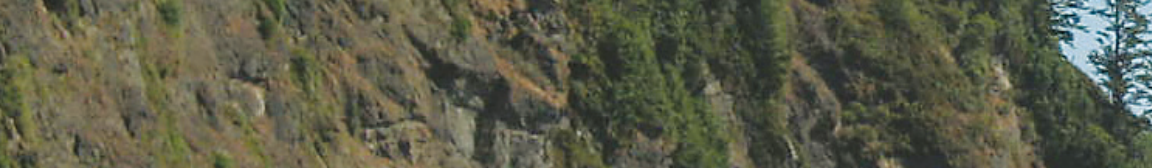

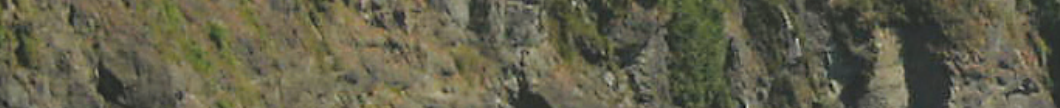
Swit

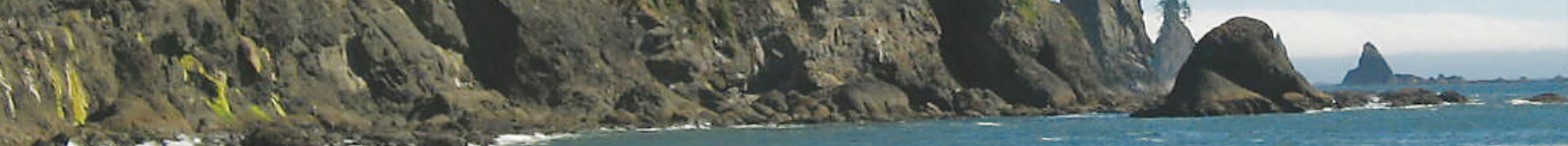

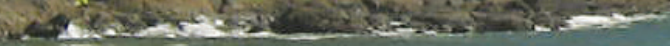

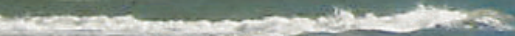

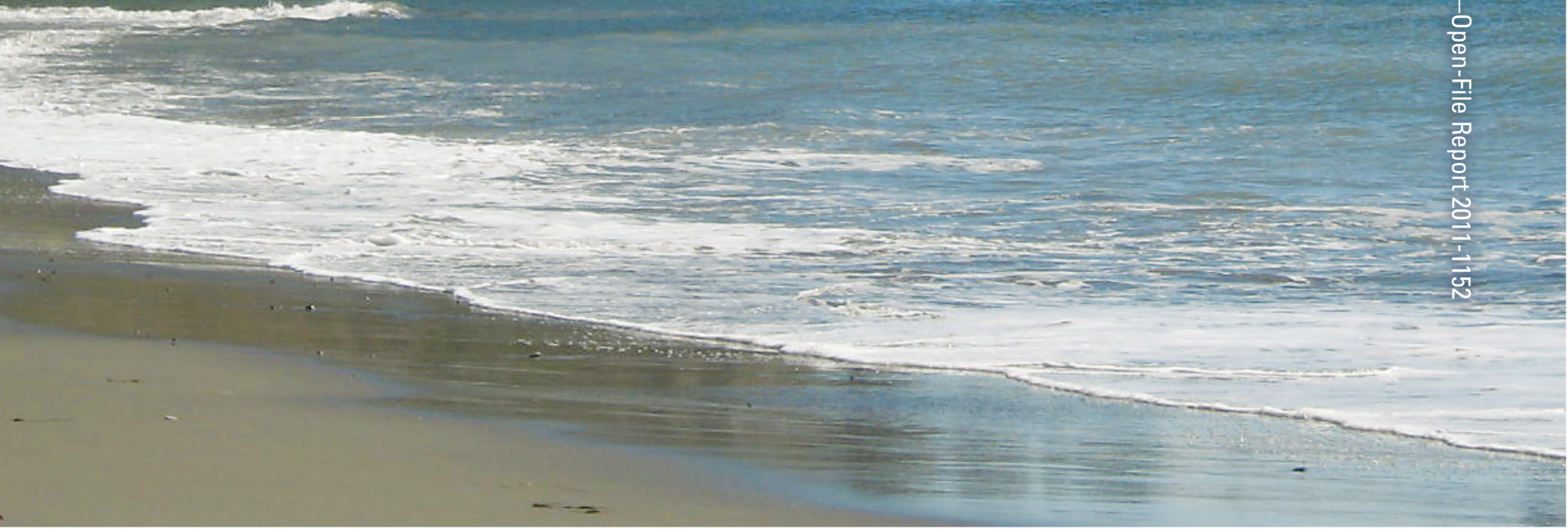

